\title{
KIRKŠNINE் ŠLAPIMO PŪSLĖS IŠVARŽA: KLINIKINIS ATVEJIS
}

\author{
Jonas Jurgaitiss ${ }^{1,2}$, Emilija Dedelytė ${ }^{3}$, Dainius Šimčikas ${ }^{2}$, Mindaugas Stravinskas ${ }^{1}$, \\ Raimundas Venckus ${ }^{1}$, Narimantas Evaldas Samalavičius ${ }^{1}$ \\ ${ }^{1}$ Klaipedos universitetine ligonine, ${ }^{2}$ Klaipédos universitetas, \\ ${ }^{3}$ Lietuvos sveikatos moksly universitetas, Medicinos fakultetas
}

Raktažodžiai: kirkšnies išvarža, šlapimo pūslès išvarža, šlapimo pūslè.

\begin{abstract}
Santrauka
Kirkšninè šlapimo pūslès išvarža yra reta būklè, sudaranti tik 1-4 proc. kirkšnies išvaržų atvejų. Dažniausiai ši patologija išsivysto vyresniems nei 50 metų vyrams, turintiems antsvorio. Dẻl būklès retumo, dažnai netipinių simptomų ar jų nebuvimo, priešoperaciniu periodu kirkšninè šlapimo pūslès išvarža diagnozuojama itin retai (rečiau nei 7 proc. atvejų). Šios būklès neatpažinimas priešoperaciniu laikotarpiu gali būti susijęs su šlapimo pūslès bei šlapimo taku pažeidimu operacijos metu ar ịvairiomis urologinėmis komplikacijomis.
\end{abstract}

\section{Ivadas}

Kirkšninè šlapimo pūslès išvarža mašnelèje (angl. inguinoscrotal hernia - ISH) yra reta būklè, pasireiškianti mažiau nei 4 proc. pacientų, kuriems diagnozuota kirkšnies išvarža [1]. Šią būklę pirmą kartą aprašè B. Levine 1951 metais [2]. Dažniausiai kirkšnine šlapimo pūslès išvarža vystosi be specifinių simptomų, todèl mažiau nei 7 proc. atvejų diagnozuojama prieš kirkšnies išvaržos operaciją [3]. Dèl sutrikusio šlapimo pūslès ištuštinimo šlapimo pūslès išvaržos gali būti susijusios su reikšmingomis urologinėmis komplikacijomis, tokiomis kaip obstrukcinè uropatija su inkstų nepakankamumu, šlapimo takų infekcija ar šlapimo pūslès infarktas [4]. Kirkšninès šlapimo pūslès išvaržos rizikos veiksniai yra įvairūs, tačiau šios būklès išsivystymui gali turèti ịtakos pilvo ir šlapimo pūslès sienelių silpnumas (sutrikęs šlapimo pūslès tonusas arba m. detrusor silpnumas), prostatos hiperplazija, šlaplès susiaurejjimas, dubens dugno silpnumas. Kiti rizikos veiksniai - nutukimas, trauma, 50 metų ir vyresnių vyrų amžiaus grupè [5].

Klinikinė kirkšninès šlapimo pūslès išvaržos išraiška yra ivvairi, tačiau dažniausi simptomai yra kirkšnies skausmas bei patinimas [1]. Dèl neretai netipinès simptomatikos nustatyti diagnozę gali būti sudètinga, didžioji dalis pacientų neturi simptomų, todèl tokiu atveju priešoperacinè diagnozė priklauso nuo atsitiktinių radiologinių radinių [6]. Šios būklès pacientams gali pasireikšti tam tikri nespecifiniai simptomai, tokie kaip dizurija, nokturija ar hematurija [7]. Sunkesniais atvejais pacientai šlapindamiesi turi rankomis atlikti keletą mašnelès suspaudimo veiksmų (Mery simptomas). Šiuo metu chirurginis gydymas yra standartinis kirkšninès išvaržos gydymas, todèl ši būklè reikalauja kruopštaus priešoperacinio bei operacinio periodų planavimo, siekiant išvengti komplikacijų ir užtikrinti sklandžią pooperacinę eigą.

Darbo tikslas - pristatyti klinikini atvejị ir apžvelgti kirkšninès šlapimo pūslès išvaržos diagnostikos ypatumus.

\section{Klinikinis atvejis}

54 metų vyras kreipėsi ị Klaipėdos universitetinès ligoninès Skubiosios pagalbos skyrių dèl 2 savaites trunkančio šlapinimosi krauju. Apžiūrint pacientą stebima didelè, besitęsianti ị mašnelę, nesireponuojanti kirkšninè išvarža. Apklausus pacientą nustatyta, jog jis prieš 15 metų patyré pilvo traumą ir 10 metų šlapindamasis suspaudžia mašnelę (Mery's simptomas).

Pacientui atlikta pilvo ir dubens srities kompiuterinè tomografija, stebima kirkšninè - skrotaline šlapimo pūslès išvarža (1 pav.). Pacientas stacionarizuotas ị Urologijos skyrių, priimtas sprendimas dèl operacinio gydymo. Pacientas operuotas esant bendrinei nejautrai. Operacijos metu šlapimo pūslè grąžinta ị anatominę padètị, praskèlus ịstrižinius raumenis (2 pav.). Atlikta Lichtenstein hernioplastika ir perkutaninè epicistostoma. Pooperaciniu laikotarpiu komplikaciju nebuvo. Epicistostoma pašalinta po 1 ménesio.

\section{Diskusija}

Kirkšninė šlapimo pūslès išvarža sudaro tik 1-4 proc. kirkšnies išvaržų atvejų ir dažniausiai pasireiškia vyresniems nei 50 metų vyrams. Nors kirkšniné šlapimo pūslès išvarža neretais atvejais nesukelia simptomų, tačiau tie pacientai, 
kuriems jie pasireiškia, skundžiasi kapšelio edema, dizurija ar kitais rečiau pasireiškiančias simptomais. Šiame straipsnyje aprašomu atveju pacientui stebetas retesnis, tačiau gana specifiškas simptomas - dviejų veiksmų šlapinimasis, rankomis suspaudžiant išvaržą, vadinamas Mery's simptomu [3].

Ivertinus paciento rizikos veiksnius ir simptomus, ultragarsinis tyrimas, kompiuterinè tomografija (KT), magnetinio rezonanso tomografija ir cistografija yra efektyvūs diagnozès patikslinimo metodai ir gali sumažinti jatrogeninio šlapimo pūslès ar šlapimo takų pažeidimo operacijos metu riziką bei išvengti kitų urologinių komplikacijų [8]. Ultragarsinis tyrimas yra prieinamiausias ir ekonomiškiausias metodas, kirkšninès šlapimo pūslès išvaržos atveju parodantis hipoechogenišką masę, pereinančią ị kapšelị per kirkšnies kanalą [9]. Tokiu būdu šią būklę galima diferencijuoti nuo kitų patologijų, tokių kaip sèklidès vandenè, sèklidès prielipo cistos bei abscesai [10]. Kitas radiologinis tyrimas, galintis padèti atpažinti kirkšninę šlapimo pūslès išvaržą - cistografija, kurios metu galima stebèti tipinị vaizdą - ,šuns ausies“ formos šlapimo pūslę kapšelyje ir išvengti tolimesnių, išteklių reikalaujančių radiologinių tyrimų, tokių kaip kompiuterinès

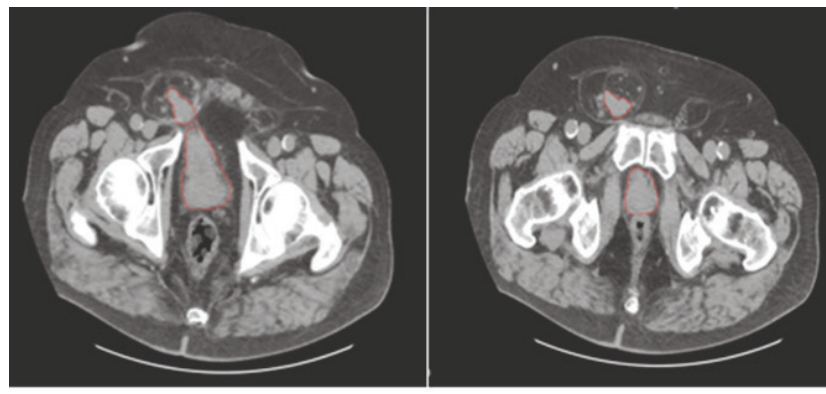

1 pav. Paciento dubens kompiuterinès tomografijos tyrimas: stebima kirkšninė šlapimo pūslès išvarža

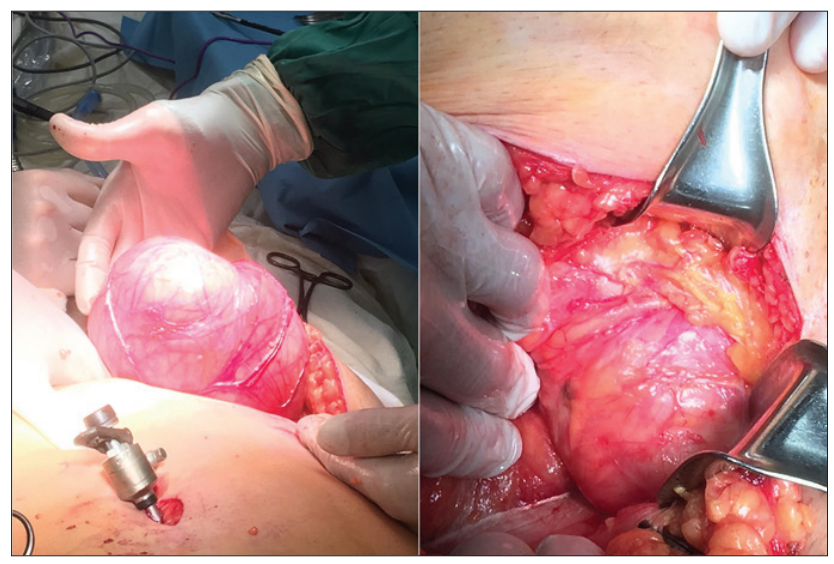

2 pav. Pacientui atlikta Lichtenstein hernioplastika: išvaržos maiše stebima šlapimo pūslè tomografijos ar magnetinio rezonanso tyrimas. Tam tikrais atvejais naudinga atlikti cistoskopiją - prostatos hiperplazijai bei žymiai hematurijai įvertinti [11]. Kompiuterinès tomografijos tyrimą tikslingiausia atlikti nutukusiems, vyresniems nei 50 metų vyrams, turintiems šlapinimosi sutrikimų [12]. Nenustačius diagnozès prieš operaciją, šlapimo pūslès išvarža gali būti nustatoma operacijos metu, dažniausiai dèl jatrogeninio sužalojimo (maždaug $12 \%$ šlapimo pūslès išvaržų atvejų), arba dẻl komplikacijų po operacijos [13]. Priešoperacinè diagnostika yra itin svarbi, siekiant išvengti tolimesnio šlapimtakio sužalojimo ar perrišimo, nes tai gali sukelti grèsmingas pooperacines komplikacijas, tokias kaip sepsis, ryški hematurija ir fistulių susidarymas [12]. Pabrěžtina, jog atvejais, kai išvaržos vartų skersmuo yra mažesnis nei $5 \mathrm{~cm}$, yra šlapimo pūslès sienelès nekrozè, perforacija, divertikulas, ar kai nustatomas šlapimo pūslès navikas, indikuotina atlikti dalinę šlapimo pūslès rezekciją [14]. Tokiais atvejais pacientą nedelsiant reikètų siųsti urologo konsultacijai. Atvejais, kai indikacijų dalinei šlapimo pūslès rezekcijai nèra, šlapimo pūslè gali būti sugrąžinta ị anatominę poziciją, atliekant Lichtenstein hernioplastiką, kaip ir šiuo klinikiniu atveju. Kirkšninès šlapimo pūslès išvaržos chirurginis gydymas nèra standartizuotas, todèl chirurginis metodas priklauso nuo chirurgo ịgūdžiu ir paciento būklès. Nepaisant kokiu chirurginiu metodu pacientas yra operuojamas, svarbu kruopščiai identifikuoti kiekvieną anatominę struktūrą išvaržos maiše, kad būtų išvengta jatrogeninio pažeidimo [11].

\section{Išvados}

1. Kirkšninė šlapimo pūslès išvarža yra reta klinikinè būklè, kuri dažnai lieka neatpažinta iki chirurginès intervencijos.

2. İtarus šią būklę, radiologiniai tyrimai ir tinkamas priešoperacinis jų vertinimas yra itin svarbūs, siekiant išvengti jatrogeninio šlapimo pūslès pažeidimo operacijos metu, pooperacinių bei kitų urologinių komplikacijų.

\section{Literatūra}

1. Cybułka B, Podgórny M, Rapeła J, Wach A. Surgical Trap of a Routine Procedure. Scrotal Hernia with Concomitant Sliding of the Urinary Bladder--Case Report. Pol Przegl Chir 2015;87(11):587-91.

https://doi.org/10.1515/pjs-2016-0007

2. Levine B. Scrotal cystocele. J Am Med Assoc 1951;147(15):143941.

https://doi.org/10.1001/jama.1951.73670320003013a

3. Papatheofani V, Beaumont K, Nuessler NC. Inguinal hernia with complete urinary bladder herniation: a case report and review of the literature. Journal Surgical Case Reports 2020; 2020(1):rjz321. 
https://doi.org/10.1093/jscr/rjz321

4. Habib AS. A Rare Case of Inguinal Hernia with Complete Bladder Herniation. Case Reports Surgery 2017; 2017: 4658169. https://doi.org/10.1155/2017/4658169

5. Hamidi Madani A, Mohammadi Nikouei H, Baghani Aval H, Enshaei A, Asadollahzade A, Esmaeili S. Scrotal herniation of bladder: a case report. Iran. J Med Sci 2013;38(1):62-64.

6. Elkbuli A, Narvel RI, McKenney M, Boneva D. Inguinal bladder hernia: A case report and literature review. Int J Surg Case Rep 2019;58:208-211. https://doi.org/10.1016/j.ijscr.2019.04.040

7. Wagner AA, Arcand P, Bamberger MH. Acute renal failure resulting from huge inguinal bladder hernia. Urology 2004;64(1):156-157. https://doi.org/10.1016/j.urology.2004.03.040

8. Wang P, Huang Y, Ye J, Gao G, Zhang F, Wu H. Large sliding inguino-scrotal hernia of the urinary bladder: A case report and literature review. Medicine (Baltimore) 2018;97(13):e9998. https://doi.org/10.1097/MD.0000000000009998

9. Panagiotakis et al. Journal of Medical Case Reports 2012; 6:90. http://www.jmedicalcasereports.com/content/6/1/90

10. Catalano O. Ultrasound evaluation of inguinoscrotal bladder hernias: report of three cases. Clinical Imaging 1997;21(2):126128. https://doi.org/10.1016/S0899-7071(96)00018-6

11. Taskovska M, Janež J. Inguinal hernia containing urinary bladder-A case report. Int J Surg Case Rep. 2017;40:36-38. https://doi.org/10.1016/j.ijscr.2017.08.046

12. Karanikas M, Kofina K, Foutzitzi S, et al. Urinary bladdercontaining incarcerated inguinoscrotal hernia: a case report. J Surg Case Rep 2020;2020(11):rjaa092. https://doi.org/10.1093/jscr/rjaa092

13. Hellerstein LH, Sacks SM, Hellerstein DK. Obstructive uropathy from complete bladder and bilateral ureteral incarceration within an inguinal hernia. BMJ Case Rep 2018;2018:bcr2017222637.

https://doi.org/10.1136/bcr-2017-222637

14. Branchu B, Renard Y, Larre S, Leon P. Diagnosis and treatment of inguinal hernia of the bladder: a systematic review of the past 10 years. Turk J Urol 2018;44(5):384-388.

https://doi.org/10.5152/tud.2018.46417

\section{INGUINOSCROTAL HERNIATION OF THE URINARY BLADDER: CASE REPORT}

J. Jurgaitis, E. Dedelytė, D. Šimčikas, M. Stravinskas,

\section{R. Venckus, N.E. Samalavičius}

Keywords: Inguinal hernia, inguinoscrotal hernia, urinary bladder.

Summary

Inguinoscrotal herniation of the urinary bladder is a rare condition that occurs in only $1-4 \%$ of inguinal hernia cases. This condition usually develops in overweight men over 50 years of age. Due to the rarity of the condition, often atypical symptoms, or their absence - the inguinal bladder hernia is diagnosed in less than $7 \%$ of cases in the preoperative period. Failure to recognize this condition in the preoperative period may be associated with bladder and urinary tract damage during surgery or various urological complications. The aim of this report is to present a clinical case and to review the diagnostic methods of inguinoscrotal herniation of the urinary bladder.

Correspondence to: Jonas.Jurgaitis@outlook.com

Gauta 2021-09-28 